\title{
Shortening of dioestrus in female dogs using cloprostenol sodium at different stages of dioestrus"
}

\author{
J. Deepak¹, M. P. Unnikrishnan ${ }^{2}$, C. Jayakumar ${ }^{3}$, \\ (iD) \\ Hiron M. Harshan ${ }^{4}$ and K. D. John Martin 5 \\ Department of Animal Reproduction, Gynaecology and Obstetrics, \\ College of Veterinary and Animal Sciences, Mannuthy, Thrissur- 680651 , \\ Kerala Veterinary and Animal Sciences University, Kerala, India.
}

Citation: Deepak, J., Unnikrishnan, M. P., Jayakumar, C., Hiron, M. H. and John Martin K. D. 2021. Shortening of dioestrus in female dogs using cloprostenol sodium at different stages of dioestrus. J. Vet. Anim. Sci. 52(4): 321-324

DOI: https://doi.org/10.51966/jvas.2021.52.4.321-324

Received: 03.02.2021

Accepted: 20.02.2021

Published: 15.12 .2021

\section{Abstract}

A study was conducted in 18 healthy, fertile, non-pregnant, dioestrous female dogs to evaluate the efficacy of $P G F_{2 a}$ analogue (cloprostenol sodium) in shortening the dioestrus. Bitches that were diagnosed non-pregnant by trans-abdominal ultrasonography, on day 30 of breeding and their dioestrual stage confirmed by serum progesterone assay, were randomly allotted to three groups of six bitches each. Group I and II bitches were treated with cloprostenol sodium @ 2.5 $\mu \mathrm{g} / \mathrm{kg}$ b. wt., subcutaneously, thrice at $48 \mathrm{~h}$ interval, beginning on day 30 and 45 of last breeding, respectively. Group III animals were assigned as control and were left untreated. Fifty days from first injection of cloprostenol, serum progesterone assay was carried out among the animals in Group I and II whereas the same was done among Group III bitches on day 90 after last breeding. Among Group I and II, mean serum progesterone concentrations were $0.93 \pm 0.04$ and $0.87 \pm 0.01 \mathrm{ng} /$ $m L$, respectively whereas the level was $1.72 \pm 0.9 \mathrm{ng} / \mathrm{mL}$ among control group; highly significant difference $(p<0.01)$ existed between control and treatment groups. The present study indicated that administration of PGF $_{2 a}$ analogue during dioestrus enhances the pace of luteal regression among non-pregnant bitches.

Keywords: Dioestrus, $P G F_{2 a}$, luteolysis, non-pregnant, bitches

Running title: Shortening of dioestrus in female dogs using cloprostenol sodium

"Part of MVSc thesis submitted to Kerala Veterinary and Animal Sciences University, Pookode, Wayanad, Kerala

1. MVSc Scholar

2. Assistant Professor, Centre for pig production and research, Mannuthy, KVASU

3. Assistant Professor and Head (i/c)

4. Assistant Professor

5. Professor and Head, Department of Veterinary Surgery and Radiology

*Corresponding author: deepakjoshi8296@yahoo.co.in, Ph: 9740079125

Copyright: () 2021 Deepak et al. This is an open access article distributed under the terms of the Creative Commons Attribution 4.0 International License (http://creativecommons.org/licenses/by/4.0/), which permits unrestricted use, distribution, and reproduction in any medium, provided the original author and source are credited. 
Canines are non-seasonal, monoestrus, polytocous and spontaneous ovulators (Concannon, 2011). Their prolonged dioestrus and obligatory anoestrus extend the inter-oestrous interval (IEI) up-to 5- 12 months, eventually lowering the profitability of canine breeding industry, due to lesser frequency of puppy harvest. Further, prolonged progestational phase predisposes the bitches to severe systemic diseases like cystic endometrial hyperplasia-pyometra complex (CEH-P) and other less severe conditions like pseudo-pregnancy (Johnston et al., 2001). The present study focused on the efficiency of synthetic $\mathrm{PGF}_{2 \mathrm{a}}$ analogue, cloprostenol sodium, when administered at mid- dioestrus and 15 days later, to shorten the period of prolonged dioestrus in non-pregnant bitches, so as to reduce the IEI as well as risk of pathological conditions.

\section{Materials and methods}

Eighteen apparently healthy and fertile bitches, aged 2-8 years and diagnosed non pregnant by trans-abdominal ultrasonography on day 30 from last breeding, were selected for the study. The health status of all the bitches was validated by haematological analysis, peripheral blood smear and wet film examination as well as microscopical examination of faecal sample. Serum progesterone assay was done on the same day, to confirm dioestrus, by chemiluminiscense immune-assay (CLIA) as per manufactures instructions (Roche, cobas e 411 analyzer, USA) and expressed as $\mathrm{ng} / \mathrm{mL}$. The selected dogs were randomly allotted into three groups and treated as presented in Table 1.

Progesterone assay was repeated 50 days from first injection of cloprostenol among the animals in Group I and II whereas the same was done on day 90 after last breeding, among Group III bitches. The data obtained were tabulated and analysed statistically (Snedecor and Cochran, 1994) using one-way ANOVA and SPSS version 21.

\section{Results and discussion}

\section{Serum progesterone assay during mid- dioestrus, on the day of selection}

Mean serum progesterone concentration on day 30 from last breeding was $25.52 \pm 2.14,23.64 \pm 2.41$ and $22.47 \pm 2.46 \mathrm{ng} /$ $\mathrm{mL}$, respectively in group I, II and III. The values did not differ significantly $(p>0.05)$ between groups.

Similar values of dioestrual serum progesterone concentration of $15-80 \mathrm{ng} / \mathrm{mL}$ were reported by Concannon (2011). Ucar et al. (2018) recorded serum progesterone concentration of $32.62 \pm 2.42 \mathrm{ng} / \mathrm{ml}$ during mid dioestrus. Dioestrus has been referred to as the period of highly active corpora lutea $(\mathrm{CL})$ which secretes large amounts of progesterone (Noakes et al., 2019). Observations in the present study indicate the existence of functional $C L$ in the animals under study.

\section{Serum progesterone assay after cloprostenol administration}

Mean serum progesterone concentration after 50 days of cloprostenol administration among the bitches of treatment groups and 90 days after last breeding (late dioestrus) in control animals are presented in Table 2.

Table 1.Treatment protocol using cloprostenol sodium in shortening of dioestrus in bitches

\begin{tabular}{|c|c|l|}
\hline $\begin{array}{c}\text { Group } \\
(\mathbf{n = 6 )}\end{array}$ & Day of treatment & \multicolumn{1}{|c|}{ Treatment protocol } \\
\hline I & $\begin{array}{c}30^{\text {th }} \text { day since last breeding } \\
\text { date (Day 0) }\end{array}$ & $\begin{array}{l}\text { Cloprostenol sodium } \\
\text { injections at 48 } \mathrm{h} \text { interval }\end{array}$ \\
\hline II & $\begin{array}{c}45^{\text {th }} \text { day since last breeding } \\
\text { date (Day 0) }\end{array}$ & $\begin{array}{l}\text { cloprostenol sodium (Inj. Clostenol }-2 \mathrm{~mL} \text { ) @ } \\
\text { b.wt., s/c, three injections at } 48 \mathrm{~h} \text { interval }\end{array}$ \\
\hline III & Control & Animals were left untreated \\
\hline
\end{tabular}

*Inj. Clostenol - $2 \mathrm{~mL}$ (cloprostenol sodium $250 \mu \mathrm{g} / \mathrm{mL}$ ): Zydus Animal Heath, Cadila Healthcare Limited, Ahmedabad 
Table 2. Serum progesterone profile of the bitches under study after prostaglandin therapy $/ 90^{\text {th }}$ day of last breeding among control animals

\begin{tabular}{|c|c|c|c|}
\hline \multirow{2}{*}{ Animal no. } & \multicolumn{3}{|c|}{ Progesterone values (ng/mL) } \\
\cline { 2 - 4 } & $\begin{array}{c}\text { Group I } \\
\text { (day 80) }\end{array}$ & $\begin{array}{c}\text { Group II } \\
\text { (day 95) }\end{array}$ & $\begin{array}{c}\text { Group III } \\
\text { (day 90) }\end{array}$ \\
\hline $\mathbf{1}$ & 0.94 & 0.82 & 2.02 \\
\hline $\mathbf{2}$ & 0.92 & 0.93 & 1.78 \\
\hline $\mathbf{3}$ & 0.9 & 0.88 & 1.73 \\
\hline $\mathbf{4}$ & 0.79 & 0.86 & 1.86 \\
\hline $\mathbf{5}$ & 1.07 & 0.86 & 1.54 \\
\hline $\mathbf{6}$ & 0.86 & 0.89 & 1.41 \\
\hline Mean \pm SE & $0.93 \pm 0.04^{\mathrm{b}}$ & $0.87 \pm 0.01^{\mathrm{b}}$ & $1.72 \pm 0.9^{\mathrm{a}}$ \\
\hline
\end{tabular}

Means with different superscripts differ significantly between columns

Mean serum progesterone concentrations of $0.93 \pm 0.04$ and $0.87 \pm 0.01 \mathrm{ng} /$ $\mathrm{mL}$ in treatment group I and II, respectively indicates that the bitches have entered in to anoestrus. Okkens and Kooistra (2006) and Kustritz (2012) reported that the bitches were considered to be in anoestrous phase when the serum progesterone concentration reached $\leq 1$ $\mathrm{ng} / \mathrm{mL}$. Control animals maintained significantly higher serum progesterone (1.72 $\pm 0.9 \mathrm{ng} /$ $\mathrm{mL}$ ) than the treated animals, indicating that although serum progesterone concentration has drastically reduced from those recorded on day 30 of cycle $(22.47 \pm 2.46 \mathrm{ng} / \mathrm{mL})$, they had not entered into anoestrum phase. The dioestrous phase in non-pregnant animals may be extended up-to 55 to 100 days and could be associated with varying degree of decline in plasma progesterone levels (Groppetti et al., 2010).

Observation in the present study signifies the efficacy of prostaglandin in inducing luteolysis. Prostaglandins are proven to be more efficient during mid to later stages of dioestrus (Wichtel et al., 1990). Kowalewski et al. (2009) reported that an increase in expression of $\mathrm{PGF}_{2 \mathrm{a}}$ receptors during early to late dioestrus enables exogenous $\mathrm{PGF}_{2 \mathrm{a}}$ to act on the $\mathrm{CL}$ for induction of luteolysis. Previous study (Ucar et al., 2018) reported that multiple low doses of prostaglandins are more effective in inducing luteolysis in bitches. Drop in serum progesterone to basal levels among the treated bitches in the present study corroborates with the findings of Romagnoli (2017) who reported that administration of cloprostenol @ $2.5 \mu \mathrm{g} /$ $\mathrm{kg}$ b wt. subcutaneously, three times at $48 \mathrm{~h}$ intervals was 100 per cent effective in inducing luteolysis when used after day 30 of dioestrus.

Slow dip in serum progesterone concentration noticed among untreated bitches in the present study is in accordance with Papa and Kowalewski (2020) who reported that gradual decline in serum progesterone levels occurs from day 35 post-ovulation onwards in non-pregnant animals.

\section{Conclusion}

The results of the present study indicate that administration of cloprostenol has shortened diestrum phase and animals have entered into anoestrum at a faster pace than the normal progression to anoestrum in untreated bitches.

\section{Acknowledgement}

The authors are thankful to the Kerala Veterinary and Animal Sciences University for providing the facilities needed for carrying out the research.

\section{Conflict of interest}

The authors declare that they have no conflict of interest.

\section{References}

Concannon, P.W. 2011. Reproductive cycles of the domestic bitch. Anim. Reprod. Sci. 124: $200-210$. 
Groppetti, D., Pecile, A., Arrighi, S., Di Giancamillo, A. and Cremonesi, F. 2010. Endometrial cytology and computerized morphometric analysis of epithelial nuclei: A useful tool for reproductive diagnosis in the bitch. Theriogenology. 73: 927-941.

Johnston, S.D., Kustritz, M.V.R and Olson, P.N.S. 2001. Canine and Feline Theriogenology. W.B. Saunders Company, Philadelphia, 1204 pp.

Kowalewski, M.P., Beceriklisoy, H.B., Aslan, S., Agaoglu, A.R. and Hoffmann, B. 2009. Time related changes in luteal prostaglandin synthesis and steroidogenic capacity d u ri n g pregnancy, normal and antiprogestin induced luteolysis in the bitch. Anim. Reprod. Sci. 116: 129-138.

Kustritz, M.V.R. 2012. Managing the reproductive cycle in the bitch. Vet. Clin. North Am. Small Anim. Pract. 42: 423437.

Noakes, D.E., Parkinson, T.J. and England, G.C. 2019. Arthur's Veterinary Reproduction and Obstetrics. (10 $10^{\text {th }}$ ed.) Saunders ELSEVIER publications. $837 \mathrm{pp}$.
Okkens, A.C. and Kooistra, H.S. 2006. Anoestrus in the dog: a fascinating story. Reprod. Domest. Anim. 41: 291-296.

Papa, P.C. and Kowalewski, M.P., 2020. Factors affecting the fate of the canine corpus luteum: Potential contributors to pregnancy and nonpregnancy. Theriogenology. 150: 339-346.

Romagnoli, S., 2017. Practical use of hormones in small animal reproduction. Rev Bras Reprod. Anim. Belo Horizonte. 41: 5967.

Snedecor, G. W., \& Cochran, W. G. (1994). Statistical methods (8th ed.). Oxford \& IBH Publishing Co. company, Calcutta, India: p.265

Ucar, E.H., Cetin, H. and Atli, M.O. 2018. Effect of multiple low-dose PGF2a injections on the mature corpus luteum in nonpregnant bitches. Theriogenology. 113: 34-43.

Wichtel, J.J., Whitacre, M.D., Yates, D.J. and Van Camp, S.D., 1990. Comparison of the effects of $\mathrm{PGF}_{2 a}$ and bromocryptine in pregnant beagle bitches. Theriogenology. 33: 829-836. 